\title{
Requirements for the Article to be Published
}

1. The journal "Inzinerine Ekonomika-Engineering Economics" is issued five times a year (February, March, June, October and December).

2. Scientific articles should be presented not later than two months before the issue of a necessary number.

3. Presented articles are assessed by two experts.

4. The article should be prepared by Microsoft Word text editor.

5. The text should be laid out on A4 format $(210 \mathrm{x}$ $297 \mathrm{~mm}$ ) page with the following margins: top -20 $\mathrm{mm}$, bottom $-25 \mathrm{~mm}$, left and right $-18 \mathrm{~mm}$.

6. The article is written in the English language:

* Title of the article;

* Full name of the author;

* Author's working place and its address;

* E-mail;

* Abstract in the English language (approximately 3000 printed characters and not less than five key words;

* Introduction (the scientific problem of the article, its novelty, aim, objective, research methods);

* The text revealing who has already dealt with the problem being researched in Lithuania and foreign countries and give the surname and the year of presentation (e.g., Ciarniene, 2008);

* Conclusions;
* References (not less than 25 resources applying APA format, wide use of ISI (http://www.isinet.com/isi/) and the list of cited research publications, e.g.:

Inzinerine Ekonomika-Engineering Economics, (all the references should be noted in the text of the article);

* The summary in the Lithuanian language (9000 printed characters and not less than five key words);

* The summary in the Russian language (3000 printed characters).

7. Submitting the article to the Editorial Board, the following information should be presented:

* A resourceful review of the article;

* A guarantee note signed by the authors of the article;

* Information about the author in English and Lithuanian: full name, working place, position, scientific degree, research field and direction, tel., e-mail.

8. Authors should submit the article in the electronic form or send it by e-mail asta.stulgiene@ktu.lt

9. A recommended volume of the laid out article is 56 pages prepared according to the requirements of the laid out format.

\section{Requirements for the Electronic From of an Article}

$>14 \mathrm{pt}$

Inzinerine Ekonomika-Engineering Economics (times New Roman, 10 pt Bold, Italic)

\section{Title (Times New Roman, 14 pt, Bold)}

$>14 \mathrm{pt}$

Ramune Ciarniene, Eimene Paulaviciene (Times New Roman, 12 pt, Bold)

$>12$ pt

Kaunas University of Technology (Times New Roman, 10 pt, Italic)

K. Donelaicio str. 73, LT-44029, Kaunas, Lithuania

e-mail: (Times New Roman, 10 pt, Italic)

$>14 \mathrm{pt}$

$>12 \mathrm{pt}$ $>6 \mathrm{pt}$

\section{Information layout and editing of the article}

The text of an article should be arranged in two columns $10 \mathrm{pt}$, with $6 \mathrm{~mm}$ spacing between them. The text is written in English with 1 interval spacing. Each paragraph should be started on a new line $(0.6 \mathrm{~cm})$.
$>12 \mathrm{pt}$

Titles of sections (Time New Roman, 11 pt, Bold)

Abstract in English (Times New Roman, 10 pt, Italic)

$>6 p t$

Keywords: not less than 5 in English (Times New Roman, $10 \mathrm{pt}$, Italic) 
$>12 \mathrm{pt}$

Table layout and editing of the article

$>6 \mathrm{pt}$

The title of a table (9 pt, Bold)

\begin{tabular}{|l|l|l|l|}
\hline & Table information (8 pt) & Table information (8 pt) & Table information (8 pt) \\
\hline 1. & & & \\
\hline 2. & & & \\
\hline 3. & & & \\
\hline
\end{tabular}

$>12 \mathrm{pt}$

Diagram layout and arrangement in an article

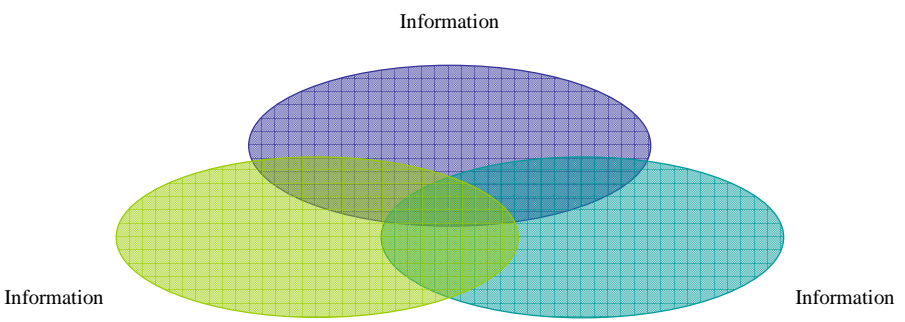

$>6 \mathrm{pt}$

$>12 \mathrm{pt}$

Figure 1. Title $(9 \mathrm{pt})$

\section{References: layout and arrangement}

The list of references is presented in two columns (10 pt) according to the alphabet. The spacing between research publications is $3 \mathrm{~mm}$, the text is written with an interval spacing, e. g.:

Malakauskaite, A., \& Navickas, V. (2010). Relation between the Level of Clusterization and Tourism Sector Competitiveness. Inzinerine Ekonomika-Engineering Economics, 21(1), 60-67.

$>3 p t$

Tamosiunas, A. (2010). Managing Corporate Strategic Changes in the Context of Climate Change. Inzinerine EkonomikaEngineering Economics, 21(1), 19-31.

Zavadskas, E. K., Turskis, Z., Ustinovichius, L., \& Shevchenko, G. (2010). Attributes Weights Determining Peculiarities in Multiple Attribute Decision Making Methods. Inzinerine Ekonomika-Engineering Economics, 21(1), 32-43.

$>12 p t$

Ramunè Čiarnienè, Eimenè Paulavičienè $(8 \mathrm{pt})$

$>6 p t$

The title of the article in the Lithuanian language $(8 \mathrm{pt}$, Bold)

$>6 p t$

Summary in the Lithuanian language ( $8 \mathrm{pt})$

$>6 \mathrm{pt}$

Keywords: in Lithuanian (8 pt) 